
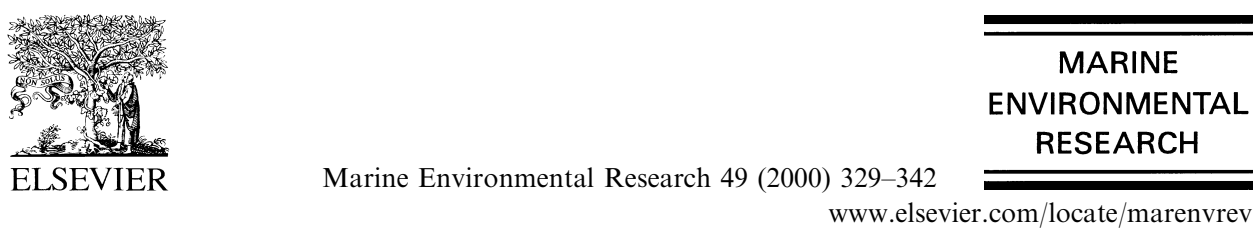

\title{
Lead in the southern East China Sea
}

\author{
Fei-Jan Lin, Shih-Chieh Hsu, Woei-Lih Jeng* \\ Institute of Oceanography, National Taiwan University, Taipei, Taiwan, Republic of China
}

Received 2 November 1998; received in revised form 21 August 1999; accepted 3 September 1999

\begin{abstract}
At present, in most oceans the lead $(\mathrm{Pb})$ biogeochemical cycling has been disturbed by anthropogenic $\mathrm{Pb}$ through atmospheric input. The $\mathrm{Pb}$ concentrations in the upper water positively correlate with atmospheric input fluxes of $\mathrm{Pb}$. The North Pacific is affected greatly by atmospheric substances via long-range transport from eastern Asia, especially from Mainland China. Mainland China may export considerable amounts of pollutants into the seas via rivers and the atmosphere owing to its recent fast growth in industry and economy. The East China Sea lies in an important geographical position - a transit between Mainland China and the western North Pacific. However, no data are available for seawater concentrations of $\mathrm{Pb}$, a representative element with anthropogenic origin. In this work seawater samples from both 5 and $30-50 \mathrm{~m}$ water layers of 15 stations occupied over a cyclonic eddy in the southern East China Sea were analyzed for particulate $\mathrm{Pb}(\mathrm{PPb})$ and dissolved $\mathrm{Pb}(\mathrm{DPb})$. The Mean concentration of $\mathrm{DPb}(\sim 128 \mathrm{ng} / \mathrm{l})$ in the southern East China Sea upper waters $(\leqslant 50 \mathrm{~m})$ is approximately several times higher than those in the Pacific; the high DPb concentrations in the southern East China Sea waters correspond to much higher atmospheric supplies of $\mathrm{Pb}$ to the East China Sea. Thus, this study partly fills the 'data gap' of the marginal seas. Also, it indicates that the East China Sea may be considerably contaminated by deposited polluted aerosols. Spatial distributions of DPb in the surface water show a tendency of increasing concentrations with distance offshore, that depends on the magnitudes of atmospheric $\mathrm{Pb}$ inputs and on particle scavenging processes. In contrast to $\mathrm{DPb}$, spatial distributions of $\mathrm{PPb}$ basically display an ' $\Omega$ '-like picture and a tendency of decreasing concentrations with distance offshore. These are related to riverine and scavenging sources and to the drive by the eddy. Additionally, the residence times of $\mathrm{DPb}$ in the surface water were estimated to be about 2 years, agreeing well with the reported data. (C) 2000 Elsevier Science Ltd. All rights reserved.
\end{abstract}

Keywords: East China Sea; Dissolved lead; Particulate lead; Biogeochemical cycle; Residence time; Scavenging

* Corresponding author. Tel.: + 886-2-23636040, ext. 301; fax: + 886-2-23626092.

E-mail address: wljeng@iodec1.oc.ntu.edu.tw (Woei-Lih Jeng). 


\section{Introduction}

In most oceans the biogeochemical cycling of lead $(\mathrm{Pb})$ has been disturbed by anthropogenic $\mathrm{Pb}$ since the beginning of the Industrial Revolution, and the disturbance has become more serious since the inception of consuming alkyl-leaded gasoline. The fact was recorded in sediments and corals (Patterson, 1987; Shen \& Boyle, 1989; Veron, Lambert, Isley, Linet \& Grousset, 1987). Pb is a particle-reactive element with a strong affinity for certain particles such as clay minerals, Mn oxide, Fe oxyhydroxide and carbonate (Li, 1981; Sturchio et al., 1997; Turekian, 1977; Whitfield \& Turner, 1987). Most of the $\mathrm{Pb}$ discharged from rivers is removed from overlying water in estuaries or coastal seas (Elbaz-Poulichet, Holliger, Huang \& Martin, 1984; Schaule \& Patterson, 1981). Atmospheric transport thus becomes the major passage for many anthropogenic constituents and $\mathrm{Pb}$ from land to offshore seas. Certainly, the $\mathrm{Pb}$ fluxes into the open ocean are dominated by the atmospheric supplies (Nriagu \& Pacyna, 1988; Patterson \& Settle, 1987).

The western North Pacific receives a large influx of mineral particles and pollutants from eastern Asia, especially from Mainland China through long-range atmospheric transport (Duce, Arimoto, Ray, Unni \& Harder, 1983; Gao, Arimoto, Zhou, Merrill \& Duce, 1992). The East China Sea (ECS), one of the largest marginal seas in the world, is situated in a transit between Mainland China and the western North Pacific. Massive quantities of terrestrial materials are emitted to the atmosphere in Mainland China (which has a rapidly developing economy and industrial base) and are deposited on the ECS shelf (Gao et al., 1996, 1997). Mainland China has been suffering from serious air pollution and acid rain owing predominantly to coal combustion by nearly two thousand power plants especially in eastern China, and by most households especially in northern China (Qian \& Zhang, 1998; Zhao \& Sun, 1986). The regional (even global) atmospheric environment could be influenced by these large discharges of $\mathrm{SO}_{2}$ (around $20 \mathrm{Mt} /$ year at present), greenhouse gases (ranking as third largest generator of the world), and trace constituents (including $\mathrm{Pb}$ ) (Dod et al., 1986). These pollutants could affect Chinese marginal seas (particularly the ECS) and the Pacific Ocean through the westerlies transport. It can therefore be expected that the ECS $\mathrm{Pb}$ system has gradually been affected by eolian inputs of $\mathrm{Pb}$.

$\mathrm{Pb}$ concentrations in sediments have been increasing in coastal regions off Mainland China since about 1980, based on the measurements of $\mathrm{Pb}$ profiles and the dating of sediment cores (Huh \& Chen, 1999). However, the impact on seawater composition corresponding to these deposited eolian constituents is not known. This work attempted to determine the extent of the contamination by eolian inputs from the analysis of seawater $\mathrm{Pb}$. At present, no data are available for dissolved $\mathrm{Pb}(\mathrm{DPb})$ concentrations in seawater of the ECS. Flegal and Patterson (1983) have suggested that the $\mathrm{DPb}$ concentrations in the surface oceans correspond directly to and correlate positively with magnitudes of atmospheric fluxes of $\mathrm{Pb}$ into the oceans. This work could examine that suggestion by taking advantage of the ECS with its unique position, neighboring the western North Pacific.

A total of 30 seawater samples were collected from both 5 and 30-50 m water layers of 15 stations occupied over a cyclonic eddy in the southern ECS off northeastern 
Taiwan, and were analyzed for both particulate $\mathrm{Pb}(\mathrm{PPb})$ and $\mathrm{DPb}$. The southern ECS is a dynamically energetic marginal sea based upon its geological, physical, chemical and biological features (Chen Lee, 1995; Hsueh, Wang \& Chern, 1992; Liu et al., 1992; Wong, Pai, Liu, Liu \& Chen, 1991). The Kuroshio Current flows along the eastern coast of Taiwan and collides with the shoaling ECS shelf when it approaches the northeastern tip of Taiwan. As a result, it causes a variety of phenomena, one of which is the development of a cyclonic eddy. Eddies can act as an important vehicle, exchanging seawater constituents between distinct water masses, particularly coastal waters and offshore waters (Hayward \& Mantyla, 1990; The Ring Group, 1981). However, the spatial distributions of metals over eddies are poorly understood (Bishop \& Fleisher, 1987; Sakamoto-Arnold, Hanson, Huizenga $\&$ Kester, 1987). Determining the influences of the cyclonic eddy on the spatial distributions of both $\mathrm{PPb}$ and $\mathrm{DPb}$ in the upper water is another goal of this work.

\section{Materials and analysis}

Seawater samples were taken from both 5 and 30-50 m water layers of the southern ECS off northeastern Taiwan during August 1994 on board National Taiwan University's R/V Ocean Researcher I. They were taken along three NE-SW parallel transects containing 15 hydrographic stations (Fig. 1) and collected using 20-1 acid-pre-cleaned GO-FLO bottles on a CTD rosette. Details of stations and hydrographic parameters are given in Table 1 . When the rosette was recovered, seawater was transferred into 20-1 PE bottles (which were rinsed twice with the seawater sample before filling) with a filling and venting closure that could prevent contamination from deck air. About 20-40 1 of seawater were pressure-filtered through a pre-cleaned and pre-weighed 142-mm $0.4-\mu \mathrm{m}$ Nuclepore polycarbonate filter using a Sartorius PTFE pressure filter holder and a Masterflex ${ }^{\circledR}$ wriggle pump. One liter filtrate was stored in acid-pre-cleaned 1-1 PP bottles and acidified to $\mathrm{pH}<2$ with Suprapur $\mathrm{HNO}_{3}$ (Merck, Germany) for subsequent analysis of dissolved trace metals in land-based laboratory. Particulate-laden filters were stored in plastic petri dishes. Seawater and particulate samples were kept in a refrigerator and a desiccator, respectively, until analysis.

After drying and weighing, particulate-laden filters were processed by the total digestion method using mixed acids of Suprapur $\mathrm{HF}, \mathrm{HNO}_{3}$ and $\mathrm{HClO}_{4}$ (all from Merck, Germany). The seawater filtrates were concentrated by using Chelex-100 resin (100-200 mesh and ammonium form) columns after adjusting $\mathrm{pH}$ to 6.5 in our land-based laboratory. Resin columns were pre-cleaned with $2 \mathrm{~N}$ Suprapur $\mathrm{HNO}_{3}$ and DDW twice before use. The elution also used $2 \mathrm{~N}$ Suprapur $\mathrm{HNO}_{3}$. All treatments for the particulate and seawater samples were carefully processed on class 100 laminar flow bench.

Metals were analyzed using a Hitachi Zeeman graphite furnace atomic absorption spectrophotometer (model Z-8100) equipped with an autosampler SSC-200. Each sample solution (digestion and elution solutions) was analyzed in triplicate at least. The quality of determination was controlled by analysis of BCSS-1 standard 


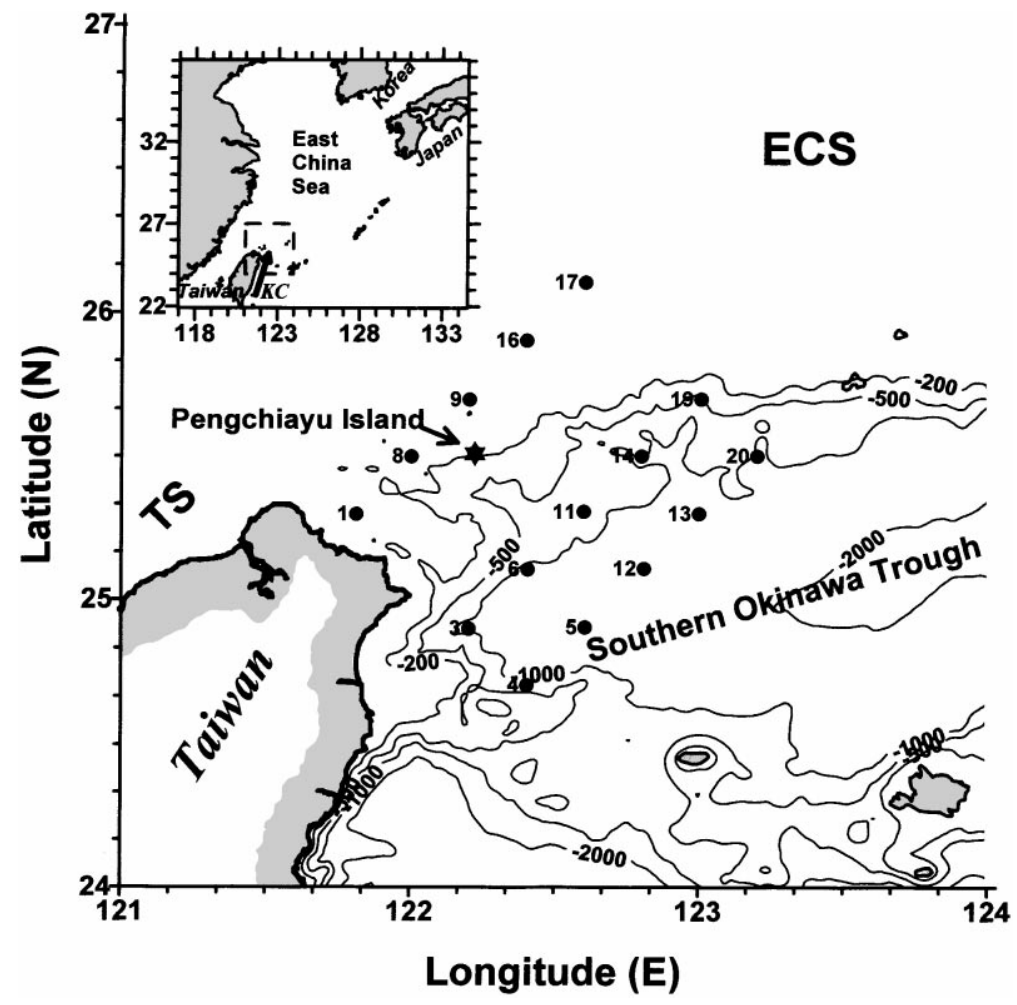

Fig. 1. Sampling locations. Inset is the regional map. The seawater collection is made along three transects: the southern East China Sea (ECS) shelf and slope and the Southern Okinawa Trough. Each transect contains five stations. An offshore island, Pengchiayu Island (shown as a star), is the collection station of marine aerosols, providing the eolian $\mathrm{Pb}$ fluxes used in the discussion of the study. Bathmetric map is also shown. TS, Taiwan Strait.

reference samples (National Research Council, Canada). Our Pb data $(19.2 \pm 0.3 \mu \mathrm{g} /$ $\mathrm{g}, n=5)$ fell at the lower end of certified value $(22.7 \pm 3.4 \mu \mathrm{g} / \mathrm{g})$. By spiking a small volume of known amounts of $\mathrm{Pb}(\mathrm{Pb}$ standard-Merck) into four separated batches of 11 duplicatedly purified seawater and by subsequent pre-concentration procedures, the recovery and precision of $\mathrm{Pb}$ for pre-concentration were obtained to be $77 \pm 3$ and $4 \%(n=5)$, respectively. No corrections were made on the DPb data because the recovery of $77 \%$ was good enough for our purposes and the reproducibility was excellent.

To estimate the procedure blank, 20-1 seawater samples, which have been purified by passing through a Chelex 100 column twice to eliminate trace metals, were taken on board as 'blank samples'. The blank samples were processed by the same procedures, including shipboard filtration and subsequent pre-concentration for filtrate in land-based laboratory, as 'real samples'. The $\mathrm{Pb}$ levels in blank samples detected in this study were much lower than those in real samples by at least one order of magnitude. 
Table 1

Station locations, temperature, salinity and both dissolved and particulate $\mathrm{Pb}(\mathrm{DPb}$ and $\mathrm{PPb})$ as well as particulate $\mathrm{Al}(\mathrm{PAl})$ and particulate $\mathrm{Mn}(\mathrm{PMn})$ concentrations in the southern East China Sea surface seawater

\begin{tabular}{|c|c|c|c|c|c|c|c|c|}
\hline $\begin{array}{l}\text { Station } \\
\text { No. }\end{array}$ & $\begin{array}{l}\text { Latitude } \\
\left({ }^{\circ} \mathrm{N}\right)\end{array}$ & $\begin{array}{l}\text { Longitude } \\
\left({ }^{\circ} \mathrm{E}\right)\end{array}$ & $\begin{array}{l}\text { Temperature } \\
\left({ }^{\circ} \mathrm{C}\right)\end{array}$ & $\begin{array}{l}\text { Salinity } \\
\text { (psu) }\end{array}$ & $\begin{array}{l}\mathrm{DPb} \\
(\mathrm{ng} / 1)\end{array}$ & $\begin{array}{l}\mathrm{PPb} \\
(\mathrm{ng} / 1)\end{array}$ & $\begin{array}{l}\mathrm{PAI}^{\mathrm{a}} \\
(\mu \mathrm{g} / \mathrm{l})\end{array}$ & $\begin{array}{l}\mathrm{PMn}^{\mathrm{b}} \\
(\mathrm{ng} / \mathrm{l})\end{array}$ \\
\hline \multicolumn{9}{|l|}{$5 \mathrm{~m}$} \\
\hline 1 & $25^{\circ} 17.88^{\prime}$ & $121^{\circ} 48.67^{\prime}$ & 25.2 & 34.04 & 99 & 15.8 & 35.1 & 456 \\
\hline 3 & $24^{\circ} 54.01^{\prime}$ & $122^{\circ} 12.04^{\prime}$ & 24.1 & 34.14 & 83 & 12.1 & 28.2 & 315 \\
\hline 4 & $24^{\circ} 42.31^{\prime}$ & $122^{\circ} 24.21^{\prime}$ & 26.4 & 33.78 & 46 & 10.5 & 9.5 & 446 \\
\hline 5 & $24^{\circ} 54.29^{\prime}$ & $122^{\circ} 36.25^{\prime}$ & 27.4 & 34.01 & 246 & 3.9 & 4.3 & 38 \\
\hline 6 & $25^{\circ} 06.28^{\prime}$ & $122^{\circ} 24.30^{\prime}$ & 25.1 & 34.13 & 224 & 12.8 & 26.9 & 385 \\
\hline 8 & $25^{\circ} 29.90^{\prime}$ & $122^{\circ} 00.05^{\prime}$ & 24.6 & 34.33 & 41 & 4.2 & 5.1 & 43 \\
\hline 9 & $25^{\circ} 41.88^{\prime}$ & $122^{\circ} 12.04^{\prime}$ & 24.8 & 34.28 & 242 & 5.3 & 9.1 & 91 \\
\hline 11 & $25^{\circ} 18.35^{\prime}$ & $122^{\circ} 35.93^{\prime}$ & 25.9 & 34.08 & 220 & 23.2 & 31.5 & 428 \\
\hline 12 & $25^{\circ} 06.46^{\prime}$ & $122^{\circ} 48.45^{\prime}$ & 27.6 & 34.15 & 177 & 9.2 & 1.0 & 10 \\
\hline 13 & $25^{\circ} 17.92^{\prime}$ & $122^{\circ} 59.87^{\prime}$ & 28.0 & 34.22 & 90 & 1.6 & 0.2 & 9 \\
\hline 14 & $25^{\circ} 29.99^{\prime}$ & $122^{\circ} 48.09^{\prime}$ & 27.2 & 34.14 & 184 & 9.8 & 1.1 & 10 \\
\hline 16 & $25^{\circ} 54.18^{\prime}$ & $122^{\circ} 23.92^{\prime}$ & 26.6 & 34.16 & 96 & 5.5 & 3.3 & 31 \\
\hline 17 & $26^{\circ} 06.25^{\prime}$ & $122^{\circ} 36.17^{\prime}$ & 26.2 & 34.22 & 132 & 4.5 & 5.1 & 101 \\
\hline 19 & $25^{\circ} 42.00^{\prime}$ & $123^{\circ} 00.26^{\prime}$ & 27.7 & 33.98 & 461 & 3.2 & 1.5 & 43 \\
\hline 20 & $25^{\circ} 29.97^{\prime}$ & $123^{\circ} 11.93^{\prime}$ & 27.9 & 34.01 & 147 & 2.9 & 8.4 & 14 \\
\hline \multicolumn{9}{|l|}{$30-50 \mathrm{~m}$} \\
\hline 1 & $25^{\circ} 17.88^{\prime}$ & $121^{\circ} 48.67^{\prime}$ & 23.0 & 34.04 & 91 & 12.7 & 32.4 & 345 \\
\hline 3 & $24^{\circ} 54.01^{\prime}$ & $122^{\circ} 12.04^{\prime}$ & 20.9 & 34.44 & 62 & 14.6 & 48.5 & 429 \\
\hline 4 & $24^{\circ} 42.31^{\prime}$ & $122^{\circ} 24.21^{\prime}$ & 23.0 & 34.57 & 82 & 6.6 & 6.7 & 48 \\
\hline 5 & $24^{\circ} 54.29^{\prime}$ & $122^{\circ} 36.25^{\prime}$ & 25.1 & 34.58 & 82 & 8.1 & 4.3 & 32 \\
\hline 6 & $25^{\circ} 06.28^{\prime}$ & $122^{\circ} 24.30^{\prime}$ & 22.8 & 34.37 & 82 & 38.7 & 39.1 & 504 \\
\hline 8 & $25^{\circ} 29.90^{\prime}$ & $122^{\circ} 00.05^{\prime}$ & 21.5 & 34.60 & 59 & 5.1 & 9.8 & 116 \\
\hline 9 & $25^{\circ} 41.88^{\prime}$ & $122^{\circ} 12.04^{\prime}$ & 22.2 & 34.66 & 124 & 5.5 & 9.4 & 90 \\
\hline 11 & $25^{\circ} 18.35^{\prime}$ & $122^{\circ} 35.93^{\prime}$ & 24.2 & 34.30 & 260 & 18.7 & 19.9 & 339 \\
\hline 12 & $25^{\circ} 06.46^{\prime}$ & $122^{\circ} 48.45^{\prime}$ & 25.6 & 34.49 & 83 & 4.4 & 0.9 & 9 \\
\hline 13 & $25^{\circ} 17.92^{\prime}$ & $122^{\circ} 59.87^{\prime}$ & 26.8 & 34.38 & 49 & 4.8 & 3.1 & 83 \\
\hline 14 & $25^{\circ} 29.99^{\prime}$ & $122^{\circ} 48.09^{\prime}$ & 25.2 & 34.64 & 280 & 8.0 & 1.5 & 16 \\
\hline 16 & $25^{\circ} 54.18^{\prime}$ & $122^{\circ} 23.92^{\prime}$ & 23.1 & 34.84 & 73 & 4.1 & 4.6 & 46 \\
\hline 17 & $26^{\circ} 06.25^{\prime}$ & $122^{\circ} 36.17^{\prime}$ & 24.7 & 34.61 & 258 & 3.3 & 1.5 & 19 \\
\hline 19 & $25^{\circ} 42.00^{\prime}$ & $123^{\circ} 00.26^{\prime}$ & 25.3 & 34.57 & 217 & 2.9 & 0.7 & 13 \\
\hline 20 & $25^{\circ} 29.97^{\prime}$ & $123^{\circ} 11.93^{\prime}$ & 26.8 & 34.35 & 517 & 4.6 & 2.6 & 13 \\
\hline
\end{tabular}

a Taken from Hsu et al. (1998).

b Taken from Hsu (1998).

\section{Results and discussion}

The circulation patterns, particularly the summertime pattern, of the study region are shown in Fig. 2. The generating mechanism of the eddy has been discussed elsewhere (Tang, Hsueh, Yang \& Ma, 1999), as have the circulation patterns of the study region (Hsu, Lin, Jeng \& Tang, 1998). 


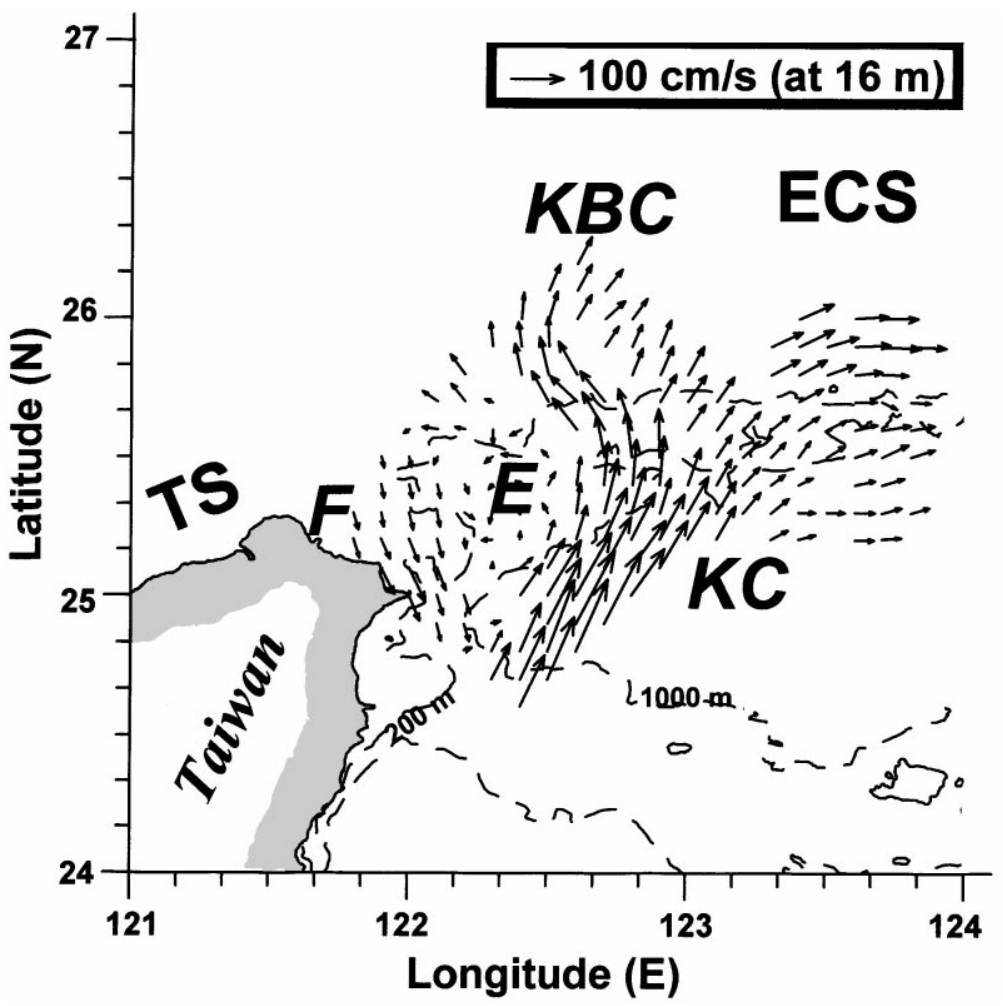

Fig. 2. Circulation pattern (current field) at $16 \mathrm{~m}$ depth of the southern East China Sea (ECS) off northern Taiwan, especially for summer season. It is measured by Shipboard Acoustic Doppler Current Profiler (Sb-ADCP) simultaneously on the same cruise as seawater sampling in this study (Tang et al., 1999). KC, Kuroshio Current; KBC, the Kuroshio Branch Current; E, the cyclonic eddy; F, the filament; TS, Taiwan Strait. This map is after Hsu et al. (1998) which gave a detailed review for the entire circulation pattern of the study area.

\subsection{Pb concentrations}

The concentrations of $\mathrm{DPb}$ and $\mathrm{PPb}$ in 30 surface seawater samples and the associated hydrographic parameters are summarized in Table 1 . DPb and $\mathrm{PPb}$ concentrations of all samples $(n=30)$ range from 41 to 517 and 1.6 to $38.7 \mathrm{ng} / \mathrm{l}$, and average $128 \pm 117$ and $6.8 \pm 7.7 \mathrm{ng} / \mathrm{l}$, respectively (Table 2). The $\mathrm{PPb}$ accounts for only a small fraction ( $<10 \%$ on average) of total $\mathrm{Pb}$ (assumed to be the sum of $\mathrm{DPb}$ and $\mathrm{PPb}$ ), agreeing well with earlier studies (Balls, 1985a; Helmers, 1996; Schaule \& Patterson, 1981). The DPb concentrations in the southern ECS surface seawaters are comparable with those (range 7-880 ng/1, average $235 \mathrm{ng} / 1$, sampling in May; range 7-800 ng/l, average $301 \mathrm{ng} / 1$, sampling in October) of the coastal seawater of southeastern China reported by Gao and Zou (1998). Their sampling area $\left(25^{\circ} 15^{\prime}-\right.$ $\left.25^{\circ} 45^{\prime} \mathrm{N}, 119^{\circ} 32^{\prime}-120^{\circ} 10^{\prime} \mathrm{E}\right)$ is approximately $250 \mathrm{~km}$ away from our study area. Also, their values and ours fall in the concentration range $(0.03-3.26 \mu \mathrm{g} / \mathrm{l}$ with a 
Table 2

Means and ranges of dissolved and particulate $\mathrm{Pb}(\mathrm{DPb}$ and $\mathrm{PPb})$ concentrations in the southern East China Sea surface seawater

\begin{tabular}{llcc}
\hline & & $\mathrm{DPb}(\mathrm{ng} / \mathrm{l})$ & $\mathrm{PPb}(\mathrm{ng} / 1)$ \\
\hline $5 \mathrm{~m}(n=15)$ & Range & $41-461$ & $1.6-23.2$ \\
& Mean & $137 \pm 107$ & $6.5 \pm 5.9$ \\
$30-50 \mathrm{~m}(n=15)$ & Range & $49-517$ & $2.9-38.7$ \\
& Mean & $119 \pm 129$ & $7.1 \pm 9.3$ \\
Overall samples $(n=30)$ & Range & $41-517$ & $1.6-38.7$ \\
& Mean & $128 \pm 117$ & $6.8 \pm 7.7$ \\
\hline
\end{tabular}

mean of $0.55 \mu \mathrm{g} / \mathrm{l})$ of the northwestern Pacific Ocean surface seawater off southern Japan $\left(28^{\circ} 30^{\prime}-36^{\circ} 30^{\prime} \mathrm{N}, 129^{\circ}-145^{\circ} \mathrm{E}\right)$ (Wang, Zou, Lu \& Jing, 1990). It has been noted that there were much higher $\mathrm{DPb}$ levels $(0.9-2.9 \mu \mathrm{g} / \mathrm{l})$ in the Changjiang River mouth water $(\mathrm{Yu}, 1995)$. The DPb concentrations in the southern ECS waters, however, are higher than those of many other oceanic regions. For example, in the Pacific, the surface concentrations of DPb are usually smaller than $20 \mathrm{ng} / \mathrm{l}$ (Flegal \& Patterson, 1983; Schaule \& Patterson, 1981), while in the Atlantic, they fall in a range of 20-75 ng/l, averaging around $30 \mathrm{ng} / \mathrm{l}$ (Boyle, Chapnick, Shen \& Bacon, 1986; Brugmann, Danielsson, Magnusson \& Westerlund, 1985; Helmers, Mart, Schulz-Baldes \& Ernst, 1990). Furthermore, the elevated DPb concentrations in surface waters from the study area are higher than those from the Mediterranean Sea but they have declined from $85 \mathrm{ng} / 1$ in 1986 to $32 \mathrm{ng} / \mathrm{lin} 1992$ (Nicolas, RuizPino, Buat-Menard \& Bethoux, 1994), and even about two times higher than those from the North Sea with an average concentration of about $60 \mathrm{ng} / 1$ (Balls, 1985b; Brugmann et al., 1985). Although surface concentratons of DPb are high, they are still reasonable, based on their relationships with atmospheric fluxes of $\mathrm{Pb}$ and the calculated $\mathrm{DPb}$ residence times comparable with literature data, as discussed below. Coupled with the above $\mathrm{Pb}$ data of the ECS, it can demonstrate that the $\mathrm{DPb}$ pool of the entire ECS may be considerably perturbed by anthropogenic $\mathrm{Pb}$.

\subsection{Spatial distributions}

Spatial distributions of $\mathrm{DPb}$ in both 5 and 30-50 m water layers are displayed in Fig. 3; those of $\mathrm{PPb}$, in Fig. 4. The concentrations of $\mathrm{DPb}$ tend to increase with distance from the Taiwan coast towards offshore. The distributions of $\mathrm{PPb}$ show an opposite pattern to those of $\mathrm{DPb}$, with decreasing concentrations seaward and with an ' $\Omega$ '-like shape. The pattern is similar to that of particulate Al (PAl) (Hsu et al., 1998) and particulate Mn (PMn) (Hsu, 1998). PPb concentrations are also strongly correlated with PAl and PMn concentrations: in $5 \mathrm{~m}$ water layer, PPb vs. PAl $r=0.82$ and $\mathrm{PPb}$ vs. PMn $r=0.81$; and in $30-50 \mathrm{~m}$ water layer, $\mathrm{PPb}$ vs. PAl $r=0.74$ and $\mathrm{PPb}$ vs. PMn $r=0.86$.

The seaward increases of the $\mathrm{DPb}$ concentrations suggest that the atmospheric $\mathrm{Pb}$ supply, predominantly from Mainland China, either by dry or wet deposition should 

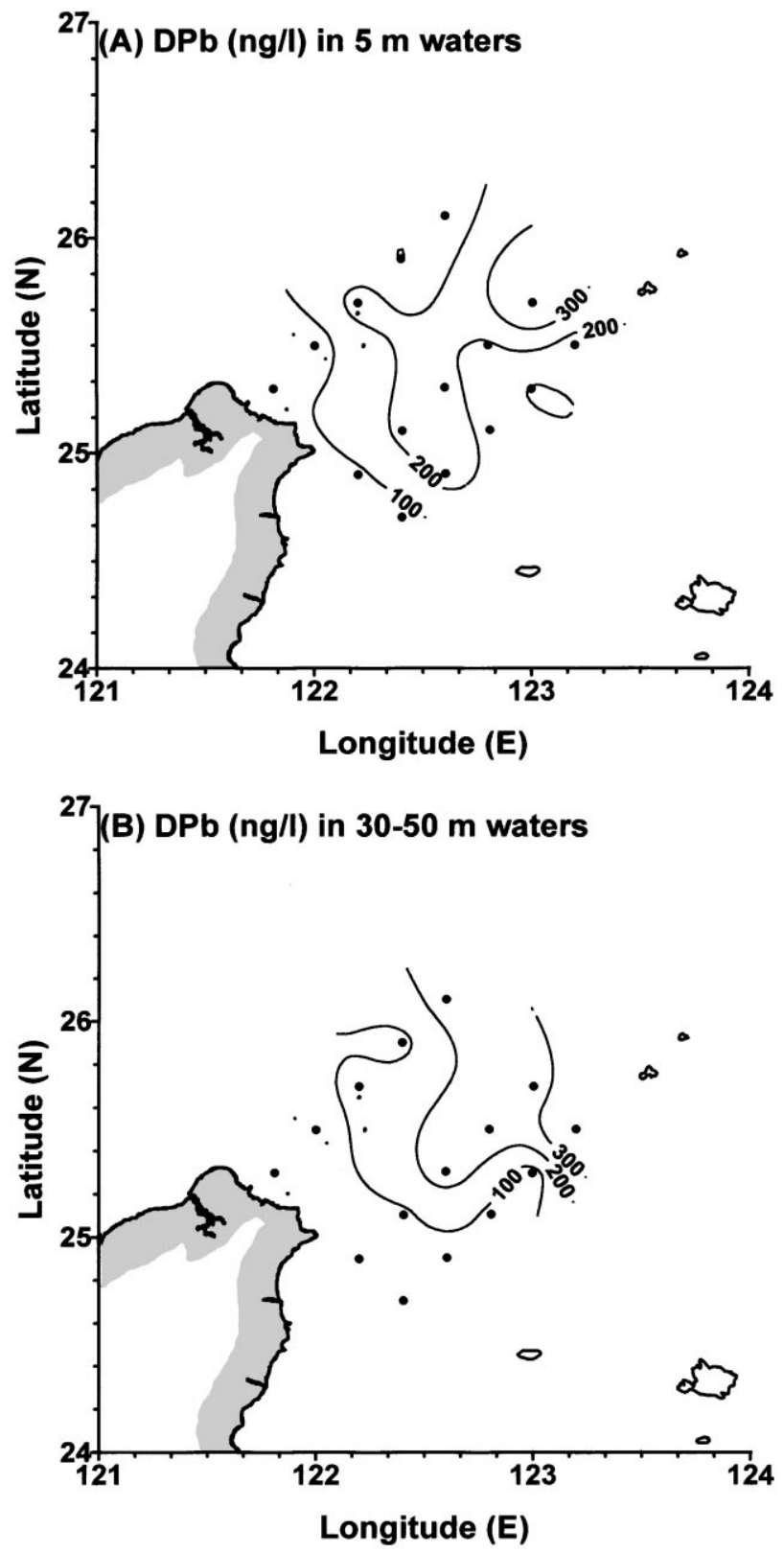

Fig. 3. Spatial distributions of dissolved $\mathrm{Pb}(\mathrm{DPb})$ in both $(\mathrm{A}) 5 \mathrm{~m}$ and $(\mathrm{B}) 30-50 \mathrm{~m}$ water layers in the southern East China Sea.

be the major source of the seawater $\mathrm{DPb}$. In fact, the total atmospheric $\mathrm{Pb}$ fluxes have been estimated to be $590 \mathrm{ng} / \mathrm{cm}^{2} /$ year (Lin, unpublished data) based on a 2-year aerosol measurement carried out on a small offshore island (Pengchiayu 

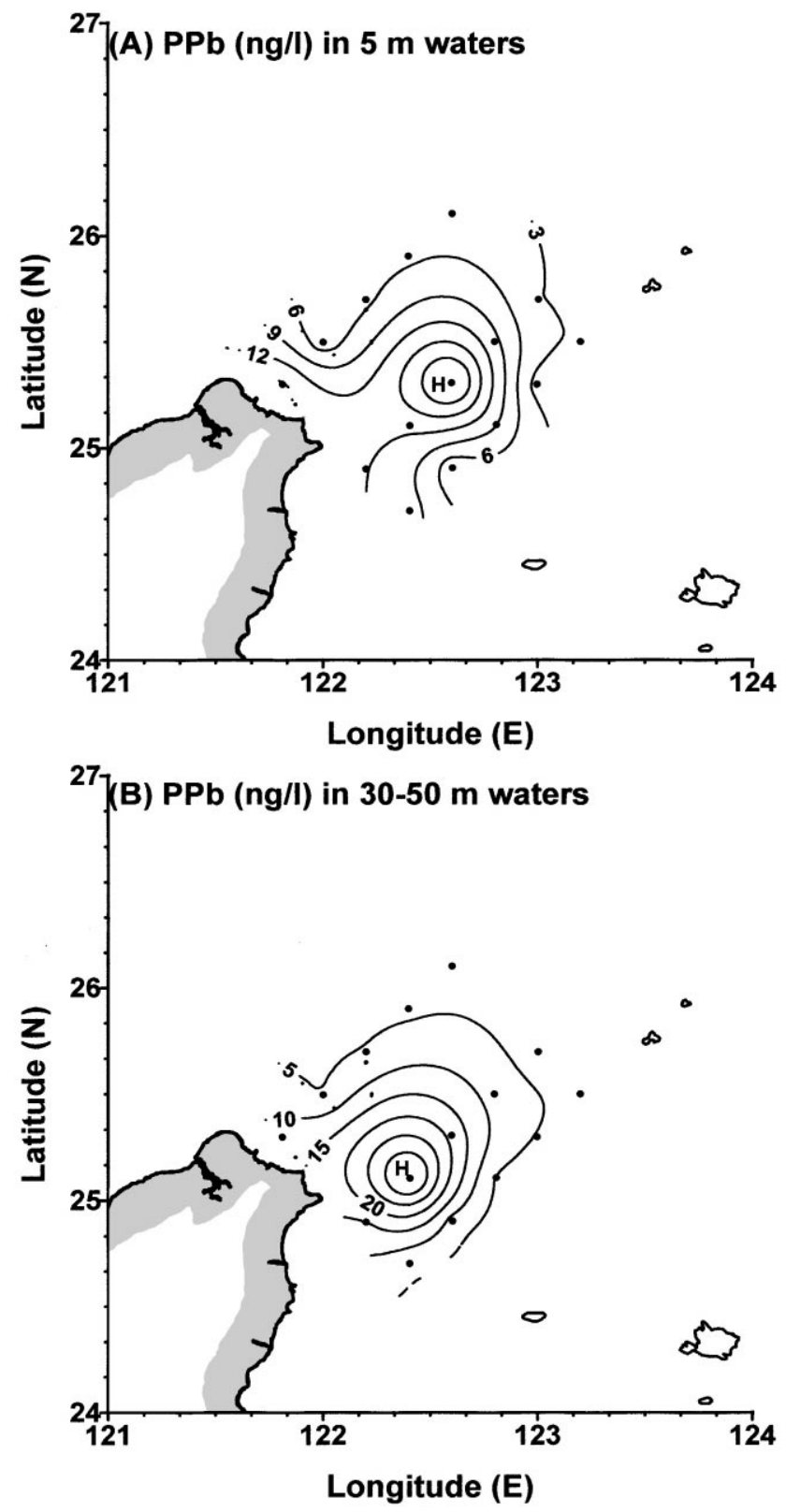

Fig. 4. Spatial distribution of particulate $\mathrm{Pb}(\mathrm{PPb})$ in both $(\mathrm{A}) 5 \mathrm{~m}$ and $(\mathrm{B}) 30-50 \mathrm{~m}$ water layers in the southern East China Sea.

Island) located in the study area (Fig. 1). These fluxes are very high compared to many coastal or marginal seas (Injuk, Van Grienek \& De Leeuw, 1998; Patterson \& Settle, 1987). Effective removal of $\mathrm{DPb}$ from overlying waters by particle scavenging 
by the high loads of suspended matter in coastal waters is another cause for the DPb variations observed (Fig. 3) (Brugmann et al., 1985; Helmers \& Rutgers van der Loeff, 1993). In addition, an examination of the DPb contour patterns shown in Fig. 3 reveals that the isopleth of $200 \mathrm{ng} / \mathrm{l}$ curves around the eddy center (Station 11). It is speculated that the cyclonic eddy over the shelf-slope of the southern ECS off northeastern Taiwan affected the $\mathrm{DPb}$ distributions by introducing high $\mathrm{DPb}$ offshore waters toward coastal area of low DPb waters. The influence of the eddy on the horizontal distributions of PAl (Al was taken as an indicator of lithogenic particles) in the region has also been described (Hsu et al., 1998).

Maximum concentrations of $\mathrm{PPb}$ occur at Station 11 in $5 \mathrm{~m}$ water layer and at Station 6 in 30-50 m water layer (Fig. 4). The distribution patterns of PPb suggest that riverine input is the major source for crustal elements (like Al and $\mathrm{Mn}$ ) and likely for anthropogenic elements (like $\mathrm{Pb}$ ) and that the cyclonic eddy drives their distributions (Hsu et al., 1998). Mean $\mathrm{Pb}: \mathrm{Al}$ ratios in seawater particulates $\left(1.36 \times 10^{-3}\right)$ are high, compared to the mean $\mathrm{Pb}$ :Al ratio of shale $\left(0.25 \times 10^{-3}\right)$ (Turekian \& Wedepohl, 1961). This indicates that $\mathrm{Pb}$ is enriched in the ECS surface seawater particulates. Coupled with the landward decrease of $\mathrm{DPb}$ concentrations, the results suggest that the $\mathrm{PPb}$ concentrations could be enhanced due to $\mathrm{DPb}$ transformation via particle scavenging processes. The aluminosilicates (or clay minerals) and manganese oxides (or manganese oxide coating onto various particles) are likely to act as an efficient scavenger to DPb (Li, 1981; Turekian, 1977; Whitfield \& Turner, 1987), as indicated by the strong correlation among PPb, PAl and PMn and concurrence of $\mathrm{PPb}, \mathrm{PAl}$ and $\mathrm{PMn}$ maxima in the region. The horizontal distributions of $\mathrm{PPb}$ are also affected by the cyclonic eddy, like those for PAl (or lithogenic particles) (Hsu et al., 1998) as indicated by the ' $\Omega$ '-like distribution.

\subsection{Relationships between DPb concentrations in upper waters and magnitudes of atmospheric $\mathrm{Pb}$ input fluxes}

Using the analytical results of this work coupled with the earlier results of other researchers, a positive correlation between surface concentrations of $\mathrm{DPb}$ and eolian $\mathrm{Pb}$ fluxes from other oceanic regions (the North Pacific, the North Atlantic and the North Sea) (Balls, 1985a,b; Boyle \& Huested, 1983; Brugmann et al., 1985; Flegal \& Patterson, 1983; Helmers et al., 1990; Injuk et al., 1998; Maring \& Duce, 1990; Maring, Patterson \& Settle, 1989; Patterson \& Settle, 1987) can be obtained (Fig. 5). This is further evidence that the sources of $\mathrm{Pb}$ pollution are eolian inputs principally from Mainland China. This contrasts to many oceans where the $\mathrm{Pb}$ concentrations are declining due to the phase-out of leaded-gasoline recently (Boyle et al., 1986; Helmers et al., 1990; Nriagu, 1996).

\subsection{Residence times of $\mathrm{DPb}$ in the surface water}

In general, the residence time $(\tau)$ of an element in seawater can be estimated by the following equation:

$$
\tau=I / F
$$




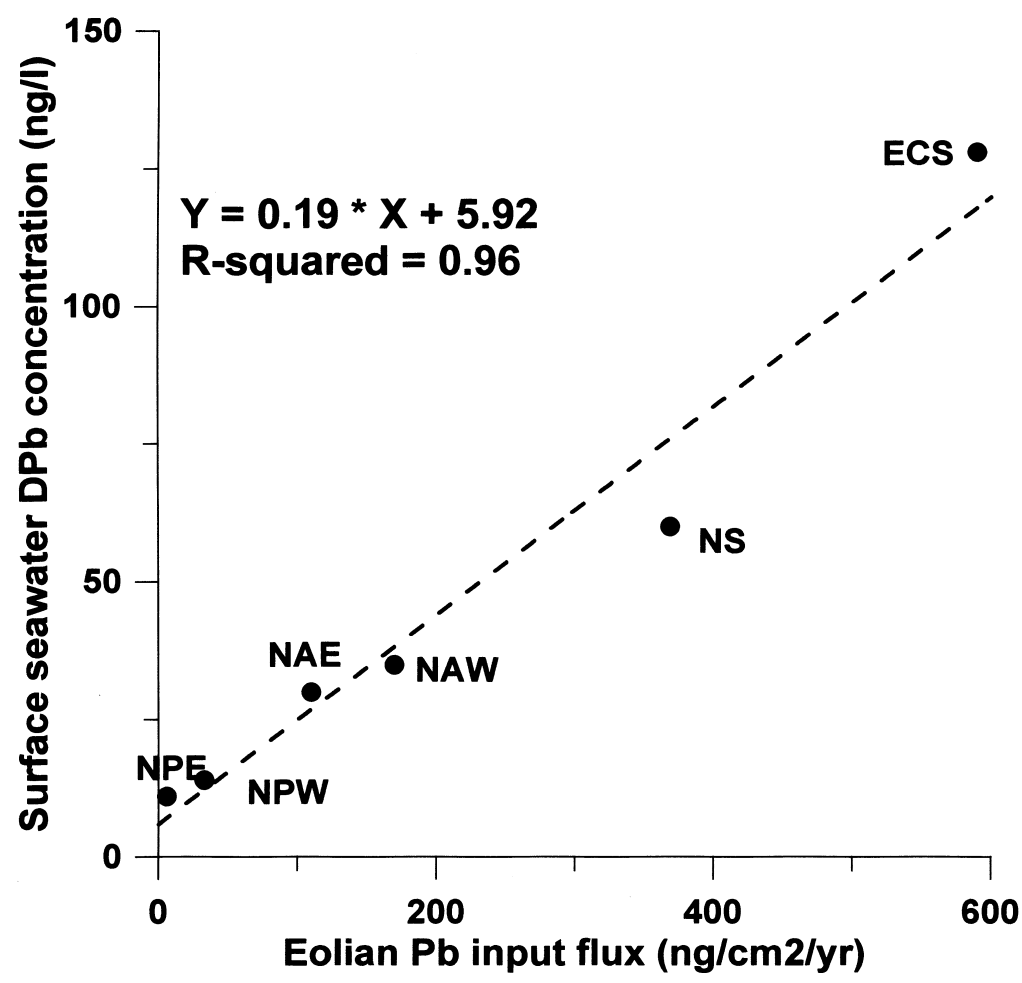

Fig. 5. Relationships between surface seawater dissolved $\mathrm{Pb}(\mathrm{DPb})$ concentration and total eolian $\mathrm{Pb}$ input flux. Sources: for the North Pacific easterlies (NPE), DPb from Flegal and Patterson (1983), eolian $\mathrm{Pb}$ from Flegal and Patterson (1983) and Maring and Duce (1990); for the North Pacific westerlies (NPW), DPb from Flegal and Patterson (1983), eolian Pb from Flegal and Patterson (1983) and Maring et al. (1989); for the North Atlantic easterlies (NAE), DPb from Helmers et al. (1990), eolian Pb from Patterson and Settle (1987); for the North Atlantic westerlies (NAW), DPb from Helmers et al. (1990) and Boyle and Huested (1983), eolian Pb from Flegal and Patterson (1983); for the North Sea (NS), DPb from Balls (1985a,b) and Brugmann et al. (1985), eolian Pb from Injuk et al. (1998); for the East China Sea (ECS), data from this study.

where $\tau$ is the residence time of a given element; $I$, the inventory of a given element in the environmental reservoir of interest; and $F$, the input or output fluxes of a given element into or from the reservoir. Under steady-state conditions, the rates of input and output are equal.

Firstly, inventories of $\mathrm{DPb}$ in the top $50 \mathrm{~m}$ at each station were calculated, and then residence times at each station could be estimated if the atmospheric input fluxes of $\mathrm{Pb}$ are available. Here we assumed the atmospheric $\mathrm{Pb}$ input fluxes to be $295 \mathrm{ng} / \mathrm{cm}^{2} /$ year based on the measurements that the total $\mathrm{Pb}$ atmospheric flux is $590 \mathrm{ng} / \mathrm{cm}^{2} /$ year (Lin, unpublished data) and the $\mathrm{Pb}$ solubility of aerosols as deposited into seawater is $50 \%$ (Duce et al., 1991).

The calculated mean residence time of $\mathrm{DPb}$ in the surface water is 2.1 years, very comparable with those estimated from ${ }^{210} \mathrm{~Pb}$ (1.8 years) in the same study region 
(Chung \& $\mathrm{Wu}, 1995)$ and also from literature data of common $\mathrm{Pb}$ or ${ }^{210} \mathrm{~Pb}(1.7-5$ years) from many seas (Bacon, Spencer \& Brewer, 1976; Nozaki, Thomson \& Turekian, 1976; Schaule \& Patterson, 1981; Veron et al., 1987). It should be mentioned that the temporal variations in surface concentrations of $\mathrm{DPb}$ and atmospheric $\mathrm{Pb}$ fluxes were not taken into account in the calculations of residence times.

\section{Summary}

In the southern ECS, DPb concentrations in upper waters are several times higher than those in the North Pacific; the pronounced DPb concentrations correspond to high atmospheric input fluxes of $\mathrm{Pb}$. The results agree well with the suggestion by Flegal and Patterson (1983) that atmospheric inputs and seawater concentrations should be correlated. Also, the results would provide background information of $\mathrm{Pb}$ concentrations for monitoring future change in the ECS seawater compositions if Mainland China gradually changes production of pollutants owing to its rapid industrialization. Distributions suggest that $\mathrm{DPb}$ is a function of atmospheric supplies of $\mathrm{Pb}$ and particle scavenging processes. Whereas for $\mathrm{PPb}$, distributions are controlled by riverine sources with an anthropogenic origin, scavenging and by eddy circulation. The $\mathrm{DPb}$ usually accounts for most $(>90 \%)$ of total $\mathrm{Pb}$; its residence times in the upper water $(50 \mathrm{~m})$ are estimated to be about 2 years.

\section{Acknowledgements}

We thank the technicians and crew of $\mathrm{R} / \mathrm{V}$ Ocean Researcher $I$ for help with sampling. Thanks are also extended to Mr. K. Huang for pre-treatment of samples. Comments by Dr. Samuel N. Luoma and two anonymous reviewers helped improve the manuscript. This work was supported by National Science Council (ROC) grants NSC 84-2611-M002A-007K2 and NSC 85-2611-M002A-026K2 to F.J.L.

\section{References}

Bacon, M. P., Spencer, D. W., \& Brewer, P. G. (1976). ${ }^{210} \mathrm{~Pb} /{ }^{210} \mathrm{Ra}$ and ${ }^{210} \mathrm{Po} /{ }^{210} \mathrm{~Pb}$ disequilibria in seawater and suspended particulate matter. Earth and Planetary Science Letters, 32, 277-296.

Balls, P. W. (1985a). Trace metals in the northern North Sea. Marine Pollution Bulletin, 16, $203-207$.

Balls, P. W. (1985b). Copper, lead and cadmium in coastal waters of the western North Sea. Marine Chemistry, 15, 363-378.

Bishop, J. K. B., \& Fleisher, M. Q. (1987). Particulate manganese dynamics in Gulf Stream warm-core rings and surrounding waters of the N.W. Atlantic. Geochimica et Cosmochimica Acta, 51, 2807-2825.

Boyle, E. A., \& Huested, S. (1983). Aspects of surface distributions of copper, nickel, cadmium and lead in the North Atlantic and North Pacific. In C. S. Wong, E. Boyle, K. W. Bruland, J. D. Burton, \& E. D. Goldberg, Trace Metals in Seawater (pp. 379-394). New York: Plenum Press.

Boyle, E. A., Chapnick, S. D., Shen, G. T., \& Bacon, M. P. (1986). Temporal variability of lead in the western North Atlantic. Journal of Geophysical Research, 91, 8573-8593.

Brugmann, L., Danielsson, L. G., Magnusson, B., \& Westerlund, S. (1985). Lead in the North Sea and the North East Atlantic Ocean. Marine Chemistry, 16, 47-60. 
Chen Lee, Y. L. (1995). Temporal and spatial changes of chlorophyll $a$ in the KEEP study waters off northeastern Taiwan. Terrestrial, Atmospheric and Oceanic Sciences, 6, 607-620.

Chung, Y., \& Wu, Y. (1995). Radioactive disequilibria among ${ }^{226} \mathrm{Ra},{ }^{210} \mathrm{~Pb}$ and ${ }^{210} \mathrm{Po}$ at the sea off northeastern Taiwan. Acta Oceanographica Taiwanica, 34, 15-29.

Dod, R. L., Giauque, R. D., Novakov, T., Su, W., Zhang, Q., \& Song, W. (1990). Sulfate and carbonaceous aerosols in Beijing, China. Atmospheric Environment, 20, 2271-2275.

Duce, R. A., Arimoto, R., Ray, B. J., Unni, C. K., \& Harder, P. J. (1983). Atmospheric trace elements at Enewetak. Journal of Geophysical Research, 88, 5321-5342.

Duce, R. A., Liss, P. S., Merrill, J. T., Atlas, E. L., Buat-Menard, P., Hicks, B. B., Miller, J. M., Prospero, J. M., Arimoto, R., Church, T. M., Ellis, W., Galloway, J. N., Hansen, L., Jickells, T. D., Knap, A. H., Reinhardt, K. H., Schneider, B., Soudine, A., Tokos, J. J., Tsunogai, S., Wollast, R., \& Zhou, M. (1991). The atmospheric input of trace species to the world ocean. Global Biogeochemical Cycles, 5 , 193-259.

Elbaz-Poulichet, F., Holliger, P., Huang, W. W., \& Martin, J. M. (1984). Lead cycling in estuaries, illustrated by the Gironde estuary, France. Nature, 308, 409-414.

Flegal, A. R., \& Patterson, C. C. (1983). Vertical concentration profiles of lead in the Central Pacific at $15^{\circ} \mathrm{N}$ and $20^{\circ} \mathrm{S}$. Earth and Planetary Science Letters, 64, 19-32.

Gao, S. Y., \& Zou, D. L. (1998). Dissolved copper, lead and cadmium in Pingtan waters, East China Sea. Chinese Journal of Oceanology and Limnology, 16, 225-230.

Gao, Y., Arimoto, R., Zhou, M. Y., Merrill, J. T., \& Duce, R. A. (1992). Relationships between the dust concentrations over eastern Asia and the remote North Pacific. Journal of Geophysical Research, 97, 9867-9872.

Gao, Y., Arimoto, R., Duce, R. A., Chen, L. Q., Zhou, M. Y., \& Gu, D. Y. (1996). Atmospheric non-seasalt sulfate, nitrate and methanesulfonate over the China Sea. Journal of Geophysical Research, 101, $12601-12611$.

Gao, Y., Arimoto, R., Duce, R. A., Zhang, X. Y., Zhang, G. Y., An, Z. S., Chen, L. Q., Zhou, M. Y., \& $\mathrm{Gu}$, D. Y. (1997). Temporal and spatial distributions of dust and its deposition to the China Sea. Tellus, $49 B, 172-189$.

Hayward, T. L., \& Mantyla, A. W. (1990). Physical, chemical and biological structure of a coastal eddy near Cape Mendocino. Journal of Marine Research, 48, 825-850.

Helmers, E. (1996). Trace metals in suspended particulate matter of Atlantic Ocean surface water $\left(40^{\circ} \mathrm{N}\right.$ to $\left.20^{\circ} \mathrm{S}\right)$. Marine Chemistry, 53, 51-67.

Helmers, E., \& Rutgers van der Loeff, M. M. (1993). Lead and aluminum in Atlantic surface waters $\left(50^{\circ} \mathrm{N}\right.$ to $\left.50^{\circ} \mathrm{S}\right)$ reflecting anthropogenic and natural sources in the eolian transport. Journal of Geophysical Research, 98, 20261-20273.

Helmers, E., Mart, L., Schulz-Baldes, M., \& Ernst, W. (1990). Temporal and spatial variations of lead concentrations in Atlantic surface waters. Marine Pollution Bulletin, 21, 515-518.

Hsu, S. C. (1998). Sources and transport of sediments and trace metal geochemistry in the water column off northeastern Taiwan. PhD thesis, National Taiwan University, Taiwan.

Hsu, S. C., Lin, F. J., Jeng, W. L., \& Tang, T. Y. (1998). The effect of a cyclonic eddy on the distribution of lithogenic particles in the southern East China Sea. Journal of Marine Research, 56, 813-832.

Hsueh, Y., Wang, J., \& Chern, C. S. (1992). The intrusion of the Kuroshio across the continental shelf northeast of Taiwan. Journal of Geophysical Research, 97, 14,323-14,330.

Huh, C. A., \& Chen, H. Y. (1999). History of lead pollution recorded in East China Sea sediments. Marine Pollution Bulletin, 38, 545-549.

Injuk, J., Van Grienek, R., \& De Leeuw, G. (1998). Deposition of atmospheric trace elements into the North Sea: coastal, ship, platform measurements and model predictions. Atmospheric Environment, 32, 3011-3025.

Li, Y. H. (1981). Ultimate removal mechanisms of elements from the ocean. Geochimica et Cosmochimica Acta, 45, 1659-1664.

Liu, K. K., Gong, G. C., Shyu, C. Z., Pai, S. C., Wei, C. L., \& Chao, S. Y. (1992). Response of Kuroshio upwelling to the onset of northeast monsoon in the sea north of Taiwan: observation and a numerical simulation. Journal of Geophysical Research, 97, 12,511-12,526. 
Maring, H. B., \& Duce, R. A. (1990). The impact of atmospheric aerosols on trace metal chemistry in open ocean surface seawater, 3. Lead. Journal of Geophysical Research, 95, 5341-5347.

Maring, H. B., Patterson, C. C., \& Settle, D. M. (1989). Atmospheric input fluxes of industrial and natural $\mathrm{Pb}$ from the Westerlies to the mid-North Pacific. In Riley \& Chester, Chemical Oceanography, vol. 10 (pp. 83-106), San Diego: Calif. Academic.

Nicolas, E., Ruiz-Pino, D., Buat-Menard, P., \& Bethoux, J. P. (1994). Abrupt decrease of lead concentration in the Mediterranean sea: a response to antipollution policy. Geophysical Research Letters, 21, 2119-2122.

Nozaki, Y., Thomson, J., \& Turekian, K. K. (1976). The distribution of ${ }^{210} \mathrm{~Pb}$ and ${ }^{210} \mathrm{Po}$ in the surface waters of the Pacific Ocean. Earth and Planetary Science Letters, 32, 304-312.

Nriagu, J. O. (1996). A history of global metal pollution. Science, 272, 223-224.

Nriagu, J. O., \& Pacyna, J. M. (1988). Quantitative assessment of worldwide contamination of air, water and soils by trace metals. Nature, 333, 134-139.

Patterson, C. C. (1987). Global pollution measured by lead in mid-ocean sediments. Nature, 326, $244-245$.

Patterson, C. C., \& Settle, D. M. (1987). Review of data on eolian fluxes of industrial and natural lead to the land and seas in remote regions on a global scale. Marine Chemistry, 22, 137-162.

Qian, J., \& Zhang, K. (1998). China's desulfurization potential. Energy Policy, 26, 345-351.

Sakamoto-Arnold, C. M., Hanson Jr., A. K., Huizenga, D., \& Kester, D. R. (1987). Spatial and temporal variability of cadmium in Gulf Stream warm-core rings and associated waters. Journal of Marine Research, 45, 201-230.

Schaule, B. K., \& Patterson, C. C. (1981). Lead concentrations in the northeast Pacific: evidence for global anthropogenic perturbations. Earth and Planetary Science Letters, 54, 97-116.

Shen, G. T., \& Boyle, E. A. (1987). Lead in corals: reconstruction of historical industrial fluxes to the surface ocean. Earth and Planetary Science Letters, 82, 289-304.

Sturchio, N. C., Chiaello, R. P., Chieng, L., Lyman, P. F., Bedzyk, M. J., Qian, Y., You, H., Yee, D., Geissbuhler, P., Sorensen, L. B., Liang, Y., \& Baer, D. R. (1997). Lead adsorption at the calcite-water interface: synchrotron X-ray standing wave and X-ray reflectivity studies. Geochimica et Cosmochimica Acta, 61, 251-263.

Tang, T. Y., Hsueh, Y., Yang, Y. J., \& Ma, J. C. (1999). Continental slope flow northeast of Taiwan. Journal of Physical Oceanography, 29, 1353-1362.

The Ring Group (1981). Gulf Stream cold-core rings: their physics, chemistry, and biology. Science, 212, 1091-1100.

Turekian, K. K. (1977). The fate of metals in the oceans. Geochimica et Cosmochimica Acta, 41, 11391144.

Turekian, K. K., \& Wedepohl, K. H. (1961). Distribution of elements in some major units of the earth's crust. Geological Society of American Bulletin, 72, 175-192.

Veron, A., Lambert, C. E., Isley, A., Linet, P., \& Grousset, F. (1987). Evidence of recent lead pollution in deep north-east Atlantic sediments. Nature, 326, 278-281.

Wang, Z., Zou, F., Lu, Y., \& Jing, M. (1990). The distribution of concentration of copper and lead in the southern sea area of Japan. In Z. Su, Selected papers of Kuroshio survey, vol. 1 (pp. 419-425). Beijing, PRC: Ocean Press (in Chinese with English abstract).

Whitfield, M., \& Turner, D. R. (1987). The role of particles in regulating the composition of seawater. In W. Stumn, Aquatic surface chemistry (pp. 457-493). New York: Wiley.

Wong, G. T. F., Pai, S. C., Liu, K. K., Liu, C. T., \& Chen, C. T. A. (1991). Variability of the chemical hydrography at the frontal region between the East China Sea and the Kuroshio north-east of Taiwan. Estuarine, Coastal and Shelf Science, 33, 105-120.

$\mathrm{Yu}, \mathrm{K}$. (1995). The studies of transport routes and disposal effects for pollutants and suspended particulates in the Changjiang estuary. Donghai Marine Science, 13(Special issue), 1-84 (in Chinese).

Zhao, D., \& Sun, B. (1986). Atmospheric pollution from coal combustion in China. Journal of Air Pollution Control Association, 36, 371-374. 